\title{
A Curriculum Development Project for the Future Global Communication of Chinese students
}

\author{
Yuqi Chen ${ }^{1, a}$ \\ ${ }^{1}$ Faculty of Humanities and Social Sciences, The University of Queensland, st Lucia, Brisbane, Queensland, Australia \\ ayuqi.chen1@uq.net.au
}

\begin{abstract}
As an international language, English is used more and more frequently in international cross-cultural communication. Due to traditional China's test-oriented education, most people still cannot communicate proficiently in English in universities or even at work, which is "Dumb English". As an English teacher, the author hopes to set up a series of four-week English audio-visual lessons, use the "Content and Language Integrated Learning" (CLIL) teaching method, combine English with subject content, and establish a student-centred Educational environment. The author hopes to help the students of Hua Xia University (Pseudonym) in Shanghai, China to build awareness of Social Justice and Gender Equality, and master the ability to use English for daily communication through a novel combination of audio, video and multimedia software education.
\end{abstract}

Keywords: Global Language, CLIL, Social Justice, Gender Equality, Audio-visual Lessons, Studentcentred Education

\section{ENGLISH AS A GLOBAL LANGUAGE}

As a global language, English can be scientific communicated in a multi-language environment, such as commerce, trade, education, tourism, and various international relations, it is the first language used on internet sites, on international aviation and used for communication between non-native speakers of English [1]. In China, preschoolers have started to register for English-learning in the four-year-old, because their parents believe that proficient in English means the key to access to a wide range of opportunities, for example, to go to the ideal university, to study abroad, to find decent and well-paid jobs, especially in transnational corporations, since many international companies are all in the English environment, and the job interview adopts the all-English communication mode.

In the history of English teaching in China, we use the "Grammar-Translation" method. Its main characteristics are a systematic analysis of grammar, rote memorization, emphasis on reading and writing, and finally applied to the examination [2]. This method often leads to a common phenomenon, that is, "Dumb English" [3], which means most Chinese students cannot use English skillfully to communicate in university or work position. Therefore, as an English teacher, the author hopes to design a serious one-hour audio-visual lesson to exercise students' listening and speaking competencies by using audio, video, and multimedia software for four weeks. And this will be a series of completely learner-centered lessons, the role of the teacher in this class is only an assistant, a transformative intellectual, she will not interfere with students' interaction and communication, only monitor and maintain classroom discipline. In this series of lessons, the author wants to adopt the "CLIL" teaching method, "Content and Language Integrated Learning" refers to the teaching of any subject through a foreign language, so students learn both subject content and foreign language [4], benefiting from higher quality and meaningful input. The teacher chooses social justice and gender equity as the classroom content and combined with English teaching. In the process of curriculum design, the author will refer to the literature in terms of English teaching and CLIL teaching method, such as "Teaching English to Second Language Learners in Academic Context", "Approaches and Methods in Language Teaching" and "Creative in finding creativity in the curriculum: The CLIL second language classroom". And related literature scholars, such as Cross Russell, Richards and Rodgers, and Newton Jonathan. 


\subsection{Nature and Role of Contemporary Theories of Language Learning}

From the Sociolinguistic characteristics, the course takes place at a top 100 comprehensive university, Hua Xia University (Pseudonym) in Shanghai, China, which is the city with the fastest financial development and the most developed educational resources. All of them have passed the college entrance examination and can complete basic English reading and writing, but they have not received systematic listening and speaking teaching. Most of them want to study abroad, some of them want to work in an international company after graduation, so they are very supportive and looking forward to the beginning of this series of lessons. Most of their parents have received higher education, so they understand the importance of English in China society and its status. Besides, as a student who has studied abroad, the author deeply feels that when facing fierce competition, the one with better English competences has greater competitiveness. Therefore, she wants to teach students not only to pass the examination but also proficient in daily communication.

From a linguistic perspective, the author holds that the language is functional and lexical. First, the English use is purposeful, students need to communicate, accept, convert and exchange information in real life or classroom, rather than to regulate and organize the English teaching content with the elements of structure and grammar [5]. For example, in these serious of lessons, the author does not want to use the "GrammarTranslation" method, but the communicative one because students need to understand that language is a vehicle for offering, suggesting, and apologizing. When the teacher uses English to teach the subject of Social Justice, when the teacher answers students' questions or students communicate with each other to explore the answers, English is not only a subject but also a tool for communication. For students who have a career aspiration in multinational enterprises, when they successfully pass English interviews and adapt to the allEnglish working environment, English is the channel they used to meet the needs of the employer and to adapt to the development of the society. Therefore, the English nature of this section is intended to help students complete their goals. Second, the language is lexical. When students master a large number of words they need to use in daily-life, workplace, or classroom, they master English [6]. Academically, students' proficiency in vocabulary can help them to complete the writing of the essay and communicate with peers and teachers more professional [7]. At the beginning of the classroom activities, the teacher explains the part of speech, the meaning and the usage of the keywords in this class to the students, so that in the subsequent classroom implementation, the students can understand and capture the teacher's expression and listening test material more smoothly and accurately. Similarly, in the following oral training, students master more vocabulary expression and then practice with their peers, which is the essence of English nature in this series of lessons. Therefore, these two characteristics are the author's understanding of English and its position and function in lessons.

From a psychological perspective, language learning is a Cognitive-Code, constructed, and Socio-cultural process. First, English learning is a cognitive-code process, the PPP approach (Presentation-PracticeProduction) shows that when students understand language and its grammar, they need to practice and implement it frequently [6]. For example, in this series of lessons, the teacher uses CLIL to teach the Social Justice and Gender Equality, after students understand its content, they will be asked to carry out the following training, the listening test, student's communication, and the student's reporting on learning outcomes, all of which are the repetition and review of the knowledge and language they have learned, and when they have a sufficiently skilled representation of the lesson, they master the English learning process. Second, learning is the construction process. Language learning is a dynamic process that has both a cognitive dimension and a social dimension [6]. When the author plays an all-English video in class for the students to complete their shorthand, then check and complement each other. This is a kind of improvement to the students' cognitive dimension. At the same time, when students pose questions, explore multiple interpretations of their meaning, and the teachers act as a guide, which is the organizational form of the social dimension [7]. Finally, English learning is a Sociocultural process. Students learn a language through their communication and interaction with MKO (More Knowledgeable Other) [8]. Which means students can not only learn subject knowledge, such as information about Social Justice and Gender Equality but also a lot of English skills when they communicate and cooperate with MKO, for example, students can learn formal oral expressions and writing skills from teachers, videos, handouts, and their peer's strengths during the group discussion, which is a peer-scaffolding [9]. These techniques can become their knowledge when they are skilled in learning and implementing, so when they gradually master new knowledge and skills, they master English learning.

\section{CURRICULUM DESIGN}

In these four lessons, I will take social justice as a big theme to help students have a comprehensive understanding, and then I will focus on the teaching of the small branch of gender equality in the last two lessons. The whole class will use the Communicative method Teach students the ability to fill in words and shorthand in listening and the ability to communicate and express their inner thoughts in English. 


\subsection{Application of Contemporary Theory of Language Learning to Teaching Practice}

Lesson plan 1

\begin{tabular}{|c|c|}
\hline Time & Content \\
\hline Pre-lesson Planning & 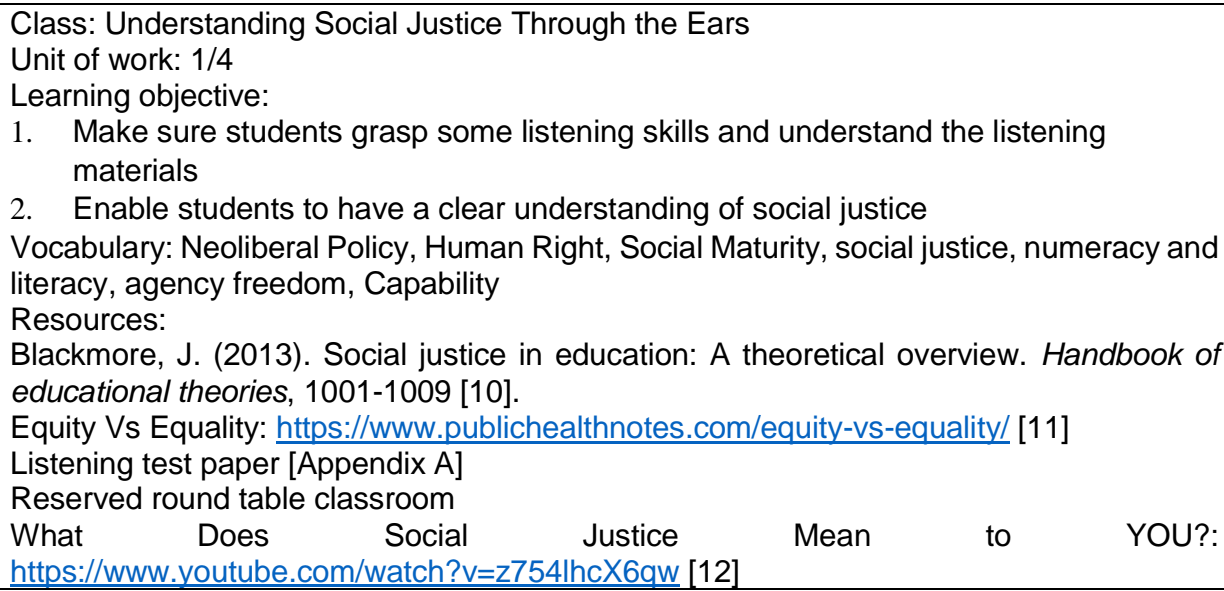 \\
\hline During lesson & $\begin{array}{l}\text { Beginning activities (10 minutes) } \\
\text {-Orientation } \\
\text { Today we will practice listening skills, I will read you the listening materials about social } \\
\text { justice for you to complete the English filling questions. And in the next class, I will teach } \\
\text { you how to complete English interviews. } \\
\text {-Ask some warm-up questions: What do you think social justice is? } \\
\text { Do you know the difference between social equity and equality? } \\
\text { Have you experienced something related to inequality whether in school or society? } \\
\text { Teaching content } \\
\text { 1.listening ( } 40 \text { minutes) } \\
\text {-Introduce some listening skills, and train students to take notes of what they hear. } \\
\text {-Explain the keywords of the listening materials and help students have a preliminary idea } \\
\text { of what Social Justice is through a video - "What Does Social Justice Mean to YOU?", } \\
\text { browse a webpage - "Social Equity and Equality". } \\
\text {-Read an excerpt from "Reopening the File on Tolerance in Teaching and Learning Across } \\
\text { Difference" and let students fill in the test paper (see Appendix A). } \\
\text {-Read the story again and let students modify their answers. } \\
\text {-Read the story one last time, gave the correct answer and let students discuss the } \\
\text { meaning of the materials in groups. } \\
\text { Conclusion (10 minutes) } \\
\text {-Review purposes of the lesson, ask students whether they have some questions and } \\
\text { whether they think the topic is challenging or easy. In the next lesson, we're going to do a } \\
\text { peer-interview based on the content of this lesson, you can prepare some interview } \\
\text { questions in advance. } \\
\text { Curriculum outcome } \\
\text { Based on the CLIL teaching method, students not only ensure their proficiency in English } \\
\text { listening skills but also understand the concept of social justice. }\end{array}$ \\
\hline Assessment & $\begin{array}{l}\text { At the end of the lesson, every student uses the Padlet to express their acquisition from } \\
\text { today's course. } \\
\text { Send more listening tests and audio to students so that they can practice after class and } \\
\text { check the answer next period. }\end{array}$ \\
\hline
\end{tabular}

\section{Lesson plan 2}

\begin{tabular}{|l|l|}
\hline Time & Content \\
\hline $\begin{array}{l}\text { Pre-lesson } \\
\text { Planning }\end{array}$ & Class: Make an interview with your peers about Social Justice \\
& $\begin{array}{l}\text { Unit of work: } 2 / 4 \\
\text { Learning objective: }\end{array}$ \\
& $\begin{array}{l}\text { 1. Enable students to have an understanding of the complete English interview } \\
\text { process. }\end{array}$ \\
& $\begin{array}{l}\text { 2. Familiarize students with the expression about cause and effect, aim and purpose } \\
\text { Vocabulary: Inequality, Equality, Inequity, Equity } \\
\text { Resources: }\end{array}$ \\
\hline
\end{tabular}




\begin{tabular}{|c|c|}
\hline & $\begin{array}{l}\text { Recording tools for each student } \\
\text { How to Ask Questions Better: https://www.youtube.com/watch?v=ALMg-7-2trY [13] }\end{array}$ \\
\hline During lesson & $\begin{array}{l}\text { Beginning activities (10 minutes) } \\
\text {-Recap of the previous lesson } \\
\text {-Orientation } \\
\text { Today we will complete the mutual interview, first I will teach you basic steps and methods. } \\
\text { In this process, I encourage you to avoid the use of L1. Each student can record the whole } \\
\text { process and replay repeatedly after class. } \\
\text { Teaching content (40minutes) } \\
\text {-Explain the inquiry method and differences of semi-structured interviews and structured } \\
\text { interviews. } \\
\text {-Watch a video about how to make an interview and how to ask questions better. } \\
\text {-Let the students do some exercises, ask whatever questions as a warm-up to establish } \\
\text { a warm and respectful interview atmosphere. } \\
\text {-Then go depth into social justice of the last class and starts the interview } \\
\text {-I will walk around in the classroom to prevent students from encountering problems or } \\
\text { obstacles } \\
\text {-At the end of this lesson, everyone shares their partner's perspective and their } \\
\text { acquisition. } \\
\text { Conclusion (10 minutes) } \\
\text {-Summarize the main points of the lesson, ask students if they have any questions, next } \\
\text { week we will focus on a small part of social justice, gender equality. } \\
\text { Curriculum outcome } \\
\text { In this lesson, students not only exercise their English academic communication } \\
\text { competencies but also understand the process of peer-interview. They expand their } \\
\text { concepts about Social Justice because they not only systematically express their ideas } \\
\text { but also gain insight from different views and perspectives, broaden their horizons. }\end{array}$ \\
\hline Assessment & $\begin{array}{l}\text { I walk around these ten groups of students during the lesson, each student has a } \\
\text { smiling face, willing to share their views, and all completed the interview process at the } \\
\text { end, they like this form of classroom, not only can contact oral English, but also } \\
\text { exchange their views with different people. }\end{array}$ \\
\hline
\end{tabular}

\section{Lesson plan 3}

\begin{tabular}{|c|c|}
\hline Time & Content \\
\hline $\begin{array}{l}\text { Pre-lesson } \\
\text { Planning }\end{array}$ & $\begin{array}{l}\text { Class: Go Depth to Gender Equality } \\
\text { Unit of work: } 3 / 4 \\
\text { Learning objective: } \\
\text { 1. Make sure students master some listening shorthand skills } \\
\text { 2. Let students have a correct attitude towards today's Gender Equality issues } \\
\text { Vocabulary: Privilege, Disadvantage, Feminism, Gender bias, Stereotype } \\
\text { Resources: } \\
\text { Introduction to Gender Concepts: https://www.youtube.com/watch?v=PbH206OHFMM } \\
\text { [14] } \\
\text { Reserved round table classroom } \\
\text { The Gender bear: https://transgenderindia.com/the-gender-bear/ [15] } \\
\text { What Is Privilege? : https://www.facebook.com/watch/?v=1936578223240531 [16] } \\
\text { Why Gender Equality Is Good for Everyone: } \\
\text { https://www.youtube.com/watch?v=7n9IOH0Nvy [17] }\end{array}$ \\
\hline During lesson & $\begin{array}{l}\text { Beginning activities ( } 20 \text { minutes) } \\
\text {-Do a warm-up activity "What Is Privilege?" to active classroom atmosphere and enhance } \\
\text { students' interests. } \\
\text { - orientation } \\
\text { Today we will mainly focus on gender equality, exercise your English listening and } \\
\text { shorthand skills. Next lesson, we will sum up and discuss the knowledge we've learned } \\
\text { over the last month. } \\
\text { Main task ( } 30 \text { minutes ) } \\
\text {-Show the picture of "Gender Bear" for students to have a first impression. } \\
\text {-Introduce some shorthand skills for materials and explain some keywords and phrases. } \\
\text {-Play the video "Why Gender Equality Is Good for Everyone" and give time for students to } \\
\text { discuss its meaning. } \\
\text {-Play the video twice, let students transfer it into their notebooks, they do not have any } \\
\text { prompt words, so they need to try their best to understand and memorize the content. } \\
\text {-Finally, play this video one last time, and I will pause at each sentence to help the } \\
\text { students improve the paragraph. }\end{array}$ \\
\hline
\end{tabular}




\begin{tabular}{|l|l|}
\hline & $\begin{array}{l}\text { Conclusion and Homework (10 minutes ) } \\
\text { Today we focus on gender equality. We had an interesting and meaningful activity at the } \\
\text { beginning, and then I guided you to complete the shorthand of English listening. Next } \\
\text { week is a large sharing class, I will focus on your speaking skills, please sum up your } \\
\text { acquisitions in advance and take turns sharing them. } \\
\text { Curriculum outcome } \\
\text { In this course, students can improve their transfer and shorthand skills and start to } \\
\text { exposure to the concept of gender equity. }\end{array}$ \\
\hline Assessment & $\begin{array}{l}\text { The difficulty of listening materials this time is increasing, and the completion of students' } \\
\text { answer is not as good as the previous week. But students eventually complete it under } \\
\text { the sentence-by-sentence playing method. }\end{array}$ \\
\hline
\end{tabular}

Lesson plan 4

\begin{tabular}{|c|c|}
\hline Time & Content \\
\hline Pre-lesson Planning & $\begin{array}{l}\text { Class: Tell Me What You Learn } \\
\text { Unit of work: } 4 / 4 \\
\text { Learning objective: } \\
\text { Enable students to talk about the different attitudes toward Social Justice and Gender } \\
\text { Equality } \\
\text { Vocabulary: } \\
\text { Social justice, Gender equity } \\
\text { Resources: } \\
\text { Reserved a big round table }\end{array}$ \\
\hline During lesson & $\begin{array}{l}\text { Beginning activities (5 minutes) } \\
\text {-Recap of the previous lesson and key vocabularies } \\
\text {-Orientation } \\
\text { Today, we will sum up all the knowledge learned in the previous three lessons, each } \\
\text { student spends } 3-5 \text { minutes to express their feelings or share their stories, I hope } \\
\text { everyone can benefit from this multicultural atmosphere. } \\
\text { Main task ( } 55 \text { minutes) } \\
-20 \text { students and } 1 \text { teacher sit around a large round table, each student sharing their input } \\
\text { in this whole English environment, everyone should maintain an inclusive and respectful } \\
\text { mood. } \\
- \text { I will not interfere with students' interaction, only to observe their performance, maintain } \\
\text { the order, and give some specific suggestions at the end. } \\
\text { Curriculum outcome } \\
\text { In this lesson, students are encouraged to express their own thoughts. All students offer } \\
\text { different views on Social Justice and Gender Equality, this is cultural integration. }\end{array}$ \\
\hline Assessment & $\begin{array}{l}\text { Individually, students are required to produce oral output, which not only improved their } \\
\text { English speaking competencies, the courage and self-confidence to speak in front of the } \\
\text { public, they learned how to get along with their classmates and analysis issues from } \\
\text { different perspectives, at the same time they sum up all the inputs, which is a successful } \\
\text { conclusion for this series of lessons. }\end{array}$ \\
\hline
\end{tabular}

\section{CONCLUSION}

Based on the literature cases and the author's previous experience in class, she designs a relatively perfect and progressive four-week course. It has many advantages to implement, first of all, the CLIL teaching method not only helps students to exercise English listening and speaking competencies, but also contacts various academic research methods, such as shorthand, interview, and round-table discussions. Secondly, the curriculum design is logical. Its difficulty is gradually progressive to help students have a more comprehensive and thorough understanding of the lesson content. Third, the course uses communication to allow all students expressing themselves, which can also make the teacher more aware of the learning progress of each student and carry out the course adjustment promptly. However, there are still rooms for progress in the lesson plans. First, it is difficult to control the time in the discussion part, so this part normally cannot be completed within the expected time, maybe the teacher could pay more attention to the control of the time and strive for every student to have an equal opportunity to show themselves. Second, students may not be able to focus on lesson content when the topic is too challenging or uninteresting. For example, when a student has no interest into social justice, they may have no perspectives to share, and lack of sensitivity to the listening material, so maybe teachers can appropriately interpenetrate some activities or videos during the lesson to enhance their learning initiative, and pose more questions for the students conducting to exercise their critical thinking. These are the suggestions put forward by 
the author and her classmates after this series of curriculum designs. Hoping in the future real teaching, the author applies these activities to help students achieve their goals. Although language acquisition is a slow and struggle process, when students complete their ideal plans, studying abroad, finding a decent job, getting a promotion, and live a satisfying life, then these efforts are worth it.

\section{AUTHORS' CONTRIBUTIONS}

Yuqi Chen is a graduate student at The University of Queensland, faculty of Faculty of Humanities and Social Sciences, school of education. She is interested in educational psychology, global education, Teaching English to Speakers of Other Languages, and the bidirectional influences of student and teacher wellbeing.

\section{ACKNOWLEDGMENTS}

The author would like to thank the Dr Sue, Dr Huong, and Dr Iffat from The University of Queensland for feedback on this piece. At the same time, the author would like to thank her parents for their financial and spiritual support for the author's learning process.

\section{APPENDIX A}

After three decades of orthodoxies focusing on individual choice and reduced investment in public education, education has become more of a positional good funded increasingly by the individual or family. At the same time, nation states have linked education more closely to the nation state's economic interests as strive to become knowledge-based economies, making education a trans-national project. Finally, no longer necessarily coincide with geographic boundaries.

Within a globalized world, education is now considered a fundamental and universal ___ and a key indicator of economic stability and ___ of nation states as argued in the Millenium Development Goals 2000. The United Nations Universal Declaration of the Rights of the Child 1990 states that children have negative rights of freedom from restriction of speech and religion, and positive social, cognitive and physical developmental rights such as right to survival, right to protection, and right to develop. Amaryta Sen and Martha Nussbaum have in this context sought to theorize __ in ways that address human rights and local context through capability theory. Sen and Nussbaum argue that there is a ___ to ___ to but that it is also in the best interests for the capabilities of each individual to be developed to their fullest Disadvantage exists, for example, when education does not provide the capability to develop and enhance other capabilities for example, Thus, basic

are insufficient as an enabling or facilitating education which provides an individual the capabilities to assess on one's capacities and goals, to weigh up evidence, assess truth claims and imagine one's future and the good life." " is about the freedom to achieve those functionings or what a person values doing and being. The capability approach is premised upon the notion of positive liberty or "___ " as choice requires a level of capability that is neither equally distributed nor innate. Education therefore should provide the freedom to develop those capabilities that impart a range of options and choices for individuals. For this reason, children need to be educated in a context that provides more than one view of the world and that encourages active participation to learn to be ___. From this reasoning, the state, for example, can intervene to prioritize over parental choice in order that the child has that freedom.

\section{REFERENCES}

[1] N. Liu, C. Lin, T. Wiley, Learner views on English and English language teaching in China, in: International Multilingual Research Journal, 2016, pp. 137-157.

DOI: https://doi.org/10.1080/19313152.2016.1147308

[2] G. Hu, English language teaching in the PRC. In R. E. Silver, G. Hu, \& M. Iino (Eds.), English language education in China, Japan, and Singapore, Singapore: National Institute of Education, National Technological University, 2002. pp. 1-78. DOI: https://doi.org/10.1080/07908310208666636

[3] R. Wei, J. Su, Zhongguo neidi waiyu shiyong qingkuang diaocha fenxi [An analysis of foreign language use in Mainland China], in: Zhongguo Shehui Yuyanxue [The Journal of Chinese Sociolinguistics], 2008, pp. 9-24.

[4] D. Coyle, P. Hood, D. Marsh, Content and language integrated learning, in: Ernst Klett Sprachen. 2010.

[5] Y. Dongmei, Teaching by Principles: An interactive Approach to Language Pedagogy, in: Journal of Asia TEFL; Seoul Vol. 14, Iss. 3, Autumn, 2017, pp. 583-584. DOI:10.18823/asiatefl.2017.14.3.17.583

[6] J. Richards, Approaches and Methods in Language Teaching, in TS Rodgers, Cambridge: Cambridge University Press, 2014.

[7] M. Williams, L. Robert, Psychology for Language Teachers: A Social Constructivist Approach, Cambridge University Press. 1997.

[8] J. Newton, W. Grabe, F. Stoller, Language Skill Development and EAP: A Reflection on Seven Key Themes, in: In Teaching English to Second Language Learners in Academic Contexts, Routledge, 2018, pp. 243-255. 
[9] B. Rogoff, Apprenticeship in thinking: Cognitive development in social context, Oxford university press, 1990.

[10] J. Blackmore, Social justice in education: A theoretical overview, in: In Irby, Beverly J., Brown, Genevieve, Lara-Alecio, Rafael and Jackson, Shirley (ed), Handbook of educational theories, Information Age Publishing, Charlotte, N.C., 2013, pp.1001-1009.

DOI: http://hdl.handle.net/10536/DRO/DU:30074551

[11] S. Adhikari, Equity Vs Equality: 20 differences, 2017 ,

DOI: https://www.publichealthnotes.com/equity-vsequality/

[12] International Labour Organization, What Does Social Justice Mean to YOU?, 2011, DOI: https://www.youtube.com/watch?v=z754lhcX6qw

[13] F. Tim, How to Ask Questions Better, 2017, DOI: https://www.youtube.com/watch?v=ALMg-7-2trY

[14] Global Teacher Prize, Teacher Training Segment 4 - Introduction to Gender Concepts, 2018, DOI: https://www.youtube.com/watch?v=PbH206OHF MM

[15] Neysara, The Gender Bear, 2016, DOI: https://transgenderindia.com/the-gender-bear/

[16] BuzzFeed Australia, What Is Privilege? 2017, DOI:

https://www.facebook.com/BuzzFeedOz/videos/19 $36578223240531 /$ ? $=1936578223240531$

[17] K. Michael, Why Gender Equality Is Good for Everyone, 2015, DOI: https://www.youtube.com/watch?v=7n9IOH0Nvy Y 